\title{
Chapter 6. Mapping Buru: The Politics of Territory and Settlement on an Eastern Indonesian Island
}

\section{Barbara Dix Grimes}

\begin{abstract}
In terms of most communication theories and common sense, a map is a scientific abstraction of reality. A map merely represents something which already exists objectively 'there.' In the history I have described [of Siam], this relationship was reversed. A map anticipated spatial reality, not vice versa. In other words, a map was a model for, rather than a model of, what it purported to represent. Thongchai (1988:110, cited in Anderson 1991:173, my emphasis)
\end{abstract}

On the most up-to-date maps of the Indonesian Province of Maluku, one will find Buru Island labelled 'District of Buru Island' (Kabupaten Pulau Buru). Buru's attainment of district status in 1999 was the result of several years of effort by delegates in the Provincial Assembly in Ambon. Before this, Buru appeared on maps merely as three 'subdistricts' (kecamatan) in the 'District of Central Maluku' (Kabupaten Maluku Tengah), governed from the district centre at Masohi on the island of Seram. ${ }^{\text {l }}$

The need to update maps of Buru is nothing new. In the 16th century, the island of Buru was claimed by the Sultan of Ternate as one of his 'dependencies'. By others, it was identified as a 'vassal' of Portugal. After the Dutch East Indies Company (Verenigde Oost-Indische Compagnie, hereafter VOC) arrived in the early 17th century and replaced the Portuguese as the predominant European power in the region, the Dutch took advantage of an earlier Portuguese-Ternate alliance to claim their own sovereignty over Buru because it had been 'land that sat under the crown of Ternate'. Later, in 1824, a colonial law resulted in the division of Buru into regencies (regentschap) as Dutch officials sought to incorporate local political systems into an overarching administration. For the next 100 years the map of Buru again changed repeatedly as the number of regencies declined gradually from 14 to seven.

For centuries foreigners have made claims and drawn maps of Buru as 'models for' their political aspirations. From Ternate, Ambon, Jakarta and other places across the sea, notions such as 'vassal', 'dependency', regentschap, kecamatan (subdistrict), desa (administrative village), and now kabupaten (district), have been mapped onto Buru. The people of Buru, however, have not always embraced these foreign concepts nor the political relationships they imply. In the mid-1980s when I first went to Buru, I was hosted by the late Raja of Regentschap Masarete. 
One of the first tasks I set for myself was to ascertain what contemporary significance was attributed to the notion of regentschap, and specifically to Regentschap Masarete. A dusty old regentschap map hung respectfully in a subdistrict office in recognition of Buru 'tradition' (adat), even though there was no correlation between the regentschap boundaries and the boundaries of the subdistrict map. I did not have to spend long, however, to realise that a territorial concept existed that was far more salient than regentschap, or even kecamatan or desa. It was the Buru concept of fena. This paper discusses how Buru discourses of territory are centred on the concept of fena, and how Buru people draw on this concept from their Austronesian heritage to interact with alternative models for territory that have been mapped onto their island.

\section{Noro and Fena: Clan and Land on Buru}

Etymologically, fena comes from the Proto-Austronesian word *benua. Blust (1987: 100) proposed the meaning of this proto-term to be 'an inhabited territory that includes not only the human population and dwellings, but also all plant and animal forms that contribute to the maintenance of the human community'. Like many other cognates of *benua, fena is primarily a territorial concept, and a very useful concept for sharing the land. On Buru, however, the fena is associated so closely with the noro - the Buru origin group or 'clan' - that the two terms not only imply each other, they can represent each other.

The inhabited or domesticated aspect of fena can be seen clearly in the Buru opposition between fena and mua. Mua is a term used primarily to refer to the vast tropical rainforests that dominate much of the island. When contrasted with fena, mua can also include open grasslands or any other uninhabited, uncultivated space, regardless of whether it would be classified by Western categories as jungle. Thus, the dichotomy of fena versus mua brings out the distinction between domesticated land versus wild or undomesticated land. People use these terms to distinguish, for example, between fafu fena, 'village or domesticated pigs' and fafu mua 'jungle or wild pigs'.

So while fena delineates the sphere of socially or humanly controlled land, the agents who control that land are a particular noro. On the basis of its origin account, each Buru clan is linked to a well-defined 'place' or 'territory' (neten) and the members of the clan are considered to be 'custodians of the territory' (geba neten duan). Such a link exists between every Buru clan and a specific territorial area on the island. These places are well defined by boundaries such as stream beds, rivers, mountain ridges, large rock formations and other topographical features. This relationship between clan and land was described by several different colonial officials who studied land tenure on Buru in the 19th century, carefully noting down the Buru term rah isin fena, 'land of the fena' (Willer 1858: 100; Wilken 1875: 12). One wrote: 
The ownership of all the lands, from the tops of the mountains to the seaside, belong, thus to the different fena; the Alfuru is very specific about this, when he says, that the fena is neten duan, that is, master of the land. The rights to the land belong to the members of the fena. (De eigendom van all de gronden, van de toppen der bergen tot aan het zeestrand, behoort dus aan de verschillende fenna's; de Alfoer drukt zich heiromtrent vrij bepaald uit, wanneer hij zegt, dat de fenna is 'nettin doean', d. i. heer (eigenaar) van de grond. Het bezit van den grond berust bij de leden der fenna.) (Wilken 1875: 12).

Later on, in the early 20th century, a Dutch missionary-scholar wrote several articles on Buru including one titled Noro en fena op Buru (Schut 1921). He also described the relationship between these two Buru concepts, arguing as we would say now, that noro refers to a kin group or clan, while fena refers to the territory of a clan.

Thus, fena is polysemous and can refer to the 'territory' (neten) of a clan, to a settlement of that clan, or to the clan itself. For example, noro Masbait refers unambiguously to the people in the Masbait clan; while fena Masbait can refer to the specific territory linked to the Masbait clan who are considered to be its 'custodians' (geba neten duan), to a settlement in which many Masbait clan members reside, or to the people in the Masbait clan. In this final sense, fena is interchangeable with noro.

\section{Living on the Land: Residence and Settlement on Buru}

When fena is compounded to fen-lale (inside a fena) this refers unambiguously to a settlement rather than the clan or the total fena territory. The link between clan and land is not contingent on custodians living on their fena land. In fact, many Buru people live on land belonging to another clan. If men 'request with respect' (laha tu hormat) to hunt, make gardens, or even to build villages on the land of others, particularly the land of their mother's brothers or brothers-in-law, their request should be granted. Since the land belonging to a clan is also constructed as the clan members' place of origin, there may be a difference between place of origin and place of residence. In any given fen-lale, there will be people from the clan considered to be 'custodian of the territory' residing in their place of origin. In addition, people from other clans will also be residing there, usually by agreement with the custodial clan.

The following table shows the number of households found in six south Buru villages and the clan affiliation of those households: 
Table 6.1. Clan affiliation of households in six Buru villages

\begin{tabular}{lllllll}
\hline $\begin{array}{l}\text { Fen-lale } \\
\text { Noro }\end{array}$ & Kudil Lahin & Mngeswaen & $\begin{array}{l}\text { Wae Nama } \\
\text { Olon }\end{array}$ & Fakal & Wae Katin & Wae Loo \\
\hline Mual & $9^{*}$ & $25^{*}$ & $7^{*}$ & 3 & 10 & - \\
Gebhain & 1 & 5 & 7 & 5 & $26^{*}$ & $20^{*}$ \\
Gewagit & - & - & 8 & 2 & 9 & 1 \\
Masbait & - & 14 & - & $22^{*}$ & 1 & 1 \\
Biloro & - & 2 & - & 5 & 1 & 2 \\
Liligoli & - & 1 & - & - & - & 5 \\
Tasane & - & 1 & - & - & - & - \\
Leslesi & - & - & - & - & - & 1 \\
Migodo & - & 1 & 1 & - & - & - \\
Outsiders & - & 1 & 1 & - & 1 & 1 \\
\hline Total & 10 & 49 & 24 & 37 & 48 & 35 \\
\hline
\end{tabular}

${ }^{*}$ Indicates the founding clan of each village.

In spite of the permanence associated with English terms such as 'village', Buru villages or settlements are not fixed centres of population concentration; they are continually impacted by a semi-nomadic lifestyle, which needs to be understood in light of several different factors. First, various seasonal activities tend to either disperse people or gather them together. Activities associated with hunting and gathering alternate with more intensive periods of agricultural activity. Buru men seek to gain a reputation as good hunters and considerable food comes from their hunting activities, particularly during the peak of east monsoon (June and July) when men 'enter the jungle' (rogo mua) to hunt the small marsupial cuscus and wild pig as an exclusively male activity. Women also gather wild vegetables and tubers from the jungle whenever possible. During the west monsoon (November to April), the activities of men and women focus on agriculture and they prefer to be in or near their gardens most of the time.

Swidden agriculture also contributes to mobility on Buru. Typical of non-volcanic islands in equatorial regions, Buru soil is relatively infertile (Bellwood 1985: 12), and shifting agriculture is needed to allow for soil replenishment. The need to make new gardens on a fairly regular basis means that village-to-garden distance increases as people remain in the same settlement over time and new gardens must be made further and further away. The further gardens are from settlements, the more days or weeks people tend to spend in their gardens without returning to the village, particularly in labour-intensive periods of clearing, planting and harvesting. After 20 years or so, it is not uncommon for entire Buru villages to move to a new location, where primary forest is available for new gardens, typical of how settlements are sometimes 'forced to move to keep up with swiddens' (Dumond 1969: 337).

This means that people might alternate between a 'village house' (hum-fena), a 'garden house' (hum-hawa; usually just a hut) and sometimes a 'hunting house' (hum-tapa; a forest hut usually associated only with men). The best way of viewing Buru residence is in terms of these several options which people have 
available to them. At certain times they might live for extended periods in their garden or in the jungle, and at other times they might return to a house in a village. These options are then multiplied, because it is possible to have several hunting huts or garden houses in different gardens several days' walk apart. In addition to the possibility of living with relatives in other villages, all this provides people with numerous options for residence and with socially significant ways to avoid conflict and asymmetric relations. A common pattern in Christian villages is for people to return to the village from their gardens on Saturday afternoon and leave again on Sunday afternoon or Monday morning after the Sunday church service.

Studies of swidden agriculture have pointed out how this type of agriculture usually requires that relatively large amounts of land per capita be available for agricultural use, and that settlements cannot remain permanently in place (Meggers 1957: 82; Dumond 1969: 337). Both these factors occur on Buru where population density is about 11 people $/ \mathrm{km}^{2}$. In addition to having limited permanence, the composition of Buru settlements varies significantly with none being very large. ${ }^{2}$ The smallest type of settlement is a single isolated garden or jungle hut for a single family or hunting party. The term 'circle of houses' (hum-lolin) can refer to a small settlement of three to 10 houses (20 to 50 people). This term refers to the settlement and the social group that lives there, as households in this type of settlement usually belong to a single lineage or sub-clan, which is also called hum-lolin. Larger settlements may have 30 to 50 households (150 to 300 people) belonging to several clans (noro). The term fen-lale (inside a fena) can be used to refer to these multi-family settlements. On the coast there are a few multi-ethnic settlements such as the subdistrict centres with more than 200 househoulds.

\section{Table 6.2. Buru settlement patterns}

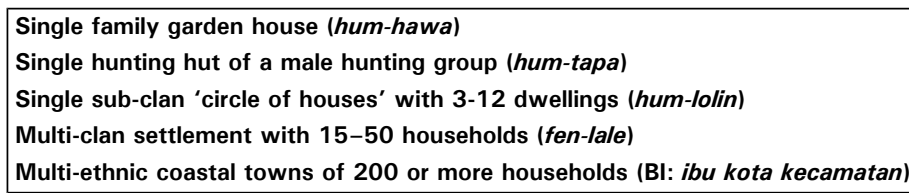

Several colonial accounts (Willer 1858; Wilken 1875; van der Miesen 1908, 1909a, 1909b) reveal how terminology to describe Buru settlements posed a dilemma to European administrators. Many settlements in the 19th century were recorded as having about 20 or 30 inhabitants although some had as many as 174 inhabitants (Willer 1858: 194). In these reports, settlements were often referred to with the Buru term hum-lolin, and one official (Willer 1858: 100) made it a point to translate hum-lolin as 'hamlet' (Dutch: gehucht) rather than 'village' (dorp) because of the small size. Others referred to them inconsistently as gehucht or dorp. 
In many places in Maluku it is commonly said that people did not live in villages until they were forcibly resettled, usually on or near the coast, by the Dutch or Indonesian Governments. It is not obvious that this occurred on Buru. In colonial accounts there is no discussion of resettling people into larger villages nor is there any oral history from that time suggesting villages were formed by forced resettlement. In fact, small villages (hum-lolin) on Buru Island today are very similar to those described in the last century. And the larger villages (50 houses) of today are not limited to areas of government intervention. Several large villages in the interior of the island remain outside the scope of government contact and service.

A more significant change in regard to Buru settlement in the past century than village size is the fact that a more sedentary lifestyle has been promoted by the Government as a prerequisite for 'national development'. Cement and tin roofing create more permanent structures than those built from traditional jungle materials and in some villages these items have been carried up the mountains with great difficulty to build schools, churches and a few individual houses. Government officials as well as imported pastors and schoolteachers encourage sedentary living and more permanent houses as a sign of modernity.

But even cement, tin roofing, churches and schools have limited impact on mobility. Explanations of why villages continue to move often have to do with sickness and multiple deaths. If too many deaths occur in a short time, it is often deemed time to abandon the village. ${ }^{3}$ New villages form as a founder, called a 'village custodian' (negri duan), gathers people together. The number of people living in a village is thus partly a reflection of an individual village custodian's charismatic ability to gather people together and to maintain a sense of solidarity. Some of the mountain villages in which churches were established by Dutch missionaries in the early 20th century still exist at the same location, although not without having endured various problems that would usually be resolved in Buru society through migration. In certain cases the pressure has become too much and even villages with Dutch churches have migrated. During my fieldwork in 1990, a large village near the lake with a prestigious reputation for having several cement houses, was abandoned and dispersed after internal disputes, with one clan returning four days' walk, halfway across the island, to their land of origin.

\section{'Where They Marry Each Other': Territory as Localised Networks of Affinity}

With the noro as the highest form of traditional political organisation and fena as the most inclusive territorial unit, at its most encompassing level Buru society is a multiplicity of localised networks of affinity. Noro are exogamous and, with high value placed on the symmetrical exchange of women between two patrilineal noro, sister exchange is an ideal marriage arrangement. It is desirable for a noro 
to have affinal relations with numerous other noro, but this does not mean every noro has such relations with every other noro, for in reality, marriage relations correlate highly with place. Clans who live near each other, frequently intermarry, while clans who live far from each other do so with far less frequency. This correlation is acknowledged openly such that places are, at least in part, defined by the marriages that occur there. A common way to explain a distant unfamiliar place is to contextualise it as the place where two specific noro 'marry each other'.

The correlation between place and marriage relations can be seen by taking an example from the Gebhain noro. Around the territory of the Gebhain noro in south Buru are two villages a day's walk apart, Wae Katin and Wae Loo. Each village has approximately 200 inhabitants or 40 households. In the village of Wae Katin, 50per cent (24/48) of the households are affiliated with the Gebhain noro and in the village of Wae Loo 65 per cent (28/43). In many of the other households there are wives who came from the Gebhain noro, so that in total, 83 per cent (40/48) of the households in Wae Katin and 88 per cent (38/43) of the households in Wae Loo have one Gebhain spouse. Yet in these two villages, the main Gebhain marriage exchange partners are not the same noro.

Table 6.3. Noro of the spouses of Gebhain clan members in the villages of Wae Katin and Wae Loo

\begin{tabular}{lll}
\hline Gebhain men whose wives are from noro & In village of Wae Katin & In village of Wae Loo \\
\hline Gewagit & 11 & 3 \\
Mual & 10 & 5 \\
Masbait & 1 & 0 \\
Hangwasit & 2 & 3 \\
Nalbessy & 0 & 1 \\
Wae Dupa & 0 & 11 \\
Wae Eno & 0 & 4 \\
Wae Kolo & 0 & 1 \\
\hline TOTAL & 24 & 28 \\
\hline & & \\
\hline Natal Gebhain women married to men in noro & In village of Wae Katin & In village of Wae Loo \\
\hline Gewagit & 7 & 1 \\
Mual & 8 & 0 \\
Hangwasit & 1 & 2 \\
Nalbessy & 0 & 4 \\
Wae Dupa & 0 & 3 \\
\hline TOTAL & 16 & 10 \\
\hline
\end{tabular}

The best way to see the relation between place and the frequency of marriage relations is to interpret these figures with reference to local geography (see Map 1). Wae Loo is further north than Wae Katin, and thus closer to Lake Rana. More than half of the marriages in Wae Loo are with noro whose origin places are around Lake Rana: Nalbessy, Wae Dupa, Wae Eno and Wae Kolo. The village associated with the Hangwasit noro, called Unet (a migration from the former 
village located at Ena Biloro), is located roughly equidistant from Wae Katin and Wae Loo. Correspondingly, there are equal numbers of Hangwasit spouses in Wae Katin and Wae Loo. The village of Wae Katin is near the 'ancestral stream' (wae moyang) of the Mual noro, at Wae Brapa, as well as being near Mngeswaen, a village associated with the Muals. Wae Katin is also near Fakal, a village associated with the Masbait noro. The numerous marriages with the Gewagit noro in Wae Katin can be explained with reference to the Gewagit origin place, a stream called Erwagit, which is near the (now former) village of Wang Karang Fatan. Between Wang Karang Fatan and the Wae Brapa River, there are several small Gewagit settlements as well.

\section{Map 1: Wae Katin, Wae Loo and surrounding villages}



From the perspective of Buru people, there is thus a strong correlation between place and marriage relations of noro. Even larger areas are conceived of in terms of the fena land of a noro. When I asked people in the interior of Buru about the meaning of Masarete, there was no attempt to identify it as a former regentschap or as a territory with a raja. To them, Masarete was a large area but an area defined as 'seven villages/lands, seven clans' (fenar pito noro pito).

\section{People of the Mountains and People of the Coast: Sharing the Land with Outsiders}

Although I have focused largely on indigenous Buru society up to this point, Buru is a multi-ethnic island and Buru people share their island with others whom they classify as 'people from across the sea' (geba fi lawe). In fact, more than 65 per cent of Buru's 110,000 inhabitants are 'immigrants' in this sense, making Buru predominantly an 'immigrant' island. Many living on the north 
and west coasts of Buru originate from the island groups of Buton and Sula. Some have carefully kept track of their family history on Buru through the generations, but today still maintain their Buton or Sula identity, language and Muslim religion. Furthermore, almost all the immigrants live at or within easy access of the coast. ${ }^{4}$ In contrast, indigenous Buru people refer to themselves as 'people of the mountains' (geb fuka) and most self-identify as Christians in the contemporary Indonesian religious context. ${ }^{5}$ As a result, the population distribution on Buru reflects multiple layers of dichotomous pairs for which central Maluku is famous: inside/outside; native/immigrant; mountain/sea; Christian/Muslim.

\section{Map 2: Coastal immigrant communities on Buru}

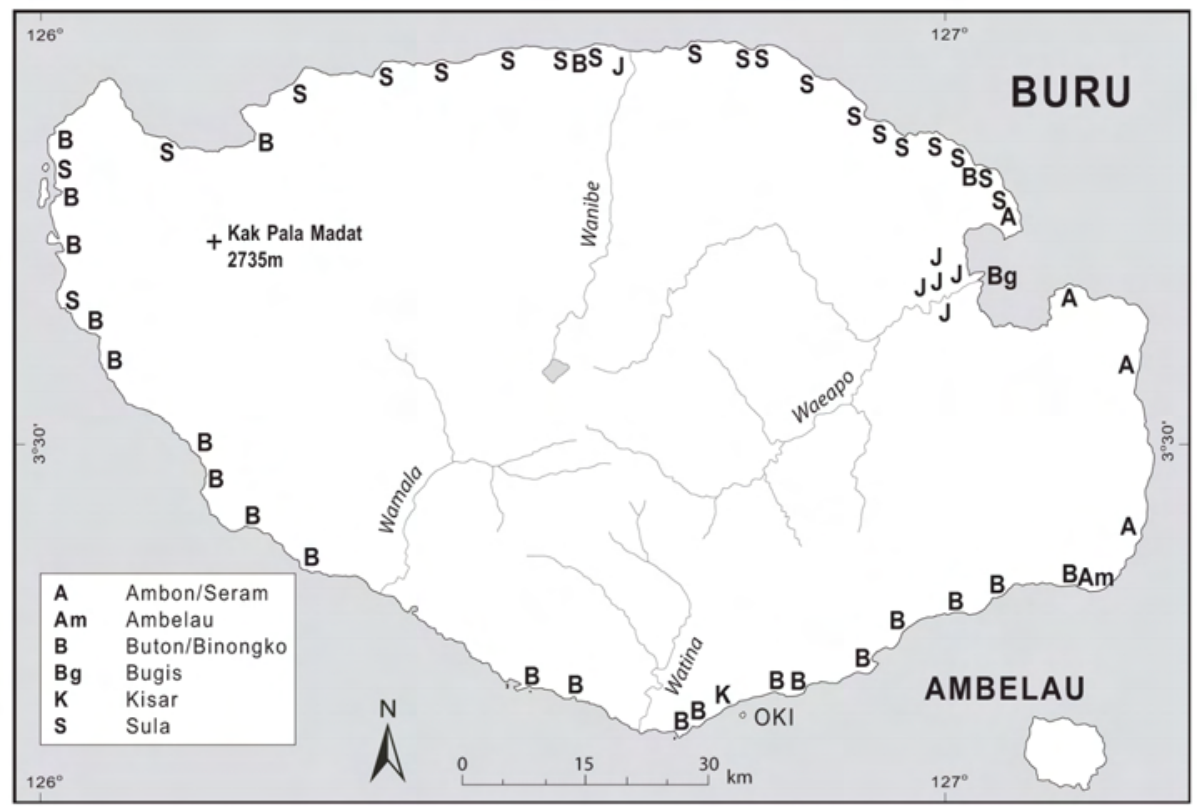

Many of the outsiders on Buru are familiar with clans or have clans as part of their own social organisation. According to the Buru people, these immigrants may have a fam (the Ambonese Malay term for clan), but they have no fena and therefore are not 'people of Buru Island'. The possession of a fena is thus the critical marker of Buru identity, distinguishing people of 'Buru mountain/island' (geb fuk Buru) from 'people from across the sea', even though some Buru clans also came from across the sea. Some Buru clans claim autochthonous origins with a founding ancestor arising from a spring or sacred place on the island. The founding ancestors of other clans came from across the sea, and when they arrived were given land by the autochthonous clans, making them custodians of a fena and, as a result, 'people of Buru island'. 
But even though some clans claim autochthonous origins and predated the clans who arrived later and were given fena land, Buru people see this as relatively unimportant and do not use it as a basis for creating asymmetrical relationships between noro. Instead, a strong discourse of equality between noro is created through the practice of sister exchange and symmetrical marriage alliances.

\section{The Colonial Creation of Raja and Regentschap: Making the Outsider King}

Buru was of no economic interest to the Portuguese or the Dutch when they arrived in Central Maluku, as there were no native clove or nutmeg trees on the island. The VOC aimed to gain a world monopoly on the trade of cloves, but it offered such low prices that people often sought out other traders (Chinese, Javanese, Makassarese) offering better prices. Cloves were a profitable enterprise for growers and traders and, by the middle of the 1600s, production was in excess of world consumption (Meilink-Roelofsz 1962: 218, 224; Chauvel 1990: 19). To make a profit, the VOC decided to curtail clove production by designating Ambon and the Lease Islands (Saparua, Haruku, Nusa Laut) as the only clove-producing areas. Each household on these islands was ordered to plant 10 new clove trees a year. To ensure that no clove trees were grown in prohibited places, each year the VOC carried out inspections throughout Central Maluku using conscripted labour for rowing services in what came to be referred to as hongi fleets.

Nevertheless, there was considerable resistance to this control. The growing of cloves and trade with other traders continued and Buru became involved. Due to its geographical position and the local terrain, which provided many excellent shelters in river mouths, Buru became an excellent place to hide boats coming from Makassar. Buru thus became a 'problem' to the VOC. Several warnings were given until, in 1648, a Dutch lieutenant and a small force were sent to south Buru where they destroyed 3,000 productive clove trees and pulled up countless smaller ones. They also managed to capture and burn down a Makassarese fort up a river and to burn several Makassarese boats (Rumphius 1910, II:50).

The VOC eventually concluded that it needed not only to expel the Makassarese from Buru and destroy the 'illegal' cloves trees there, it needed to do something about the people whom it saw as unruly and untrustworthy rebels. After capturing leaders of coastal Buru, on October 2, 1658, the VOC Governor made a treaty with them, promising pardon if the remained legal allies of the VOC and made no trading contracts with any other people. They were to move all their villages from around the entire island to a fort to be built at Kayeli in order to live under the supervision of the VOC. In addition, all clove trees on Buru were to be destroyed and these leaders were to assist the VOC in locating 
them. And finally, as they were Muslim, the VOC assured them that they would not be harassed because of their religious beliefs.

\section{Map 3: Approximate location of coastal villages removed to Kayeli Fort in 1658}

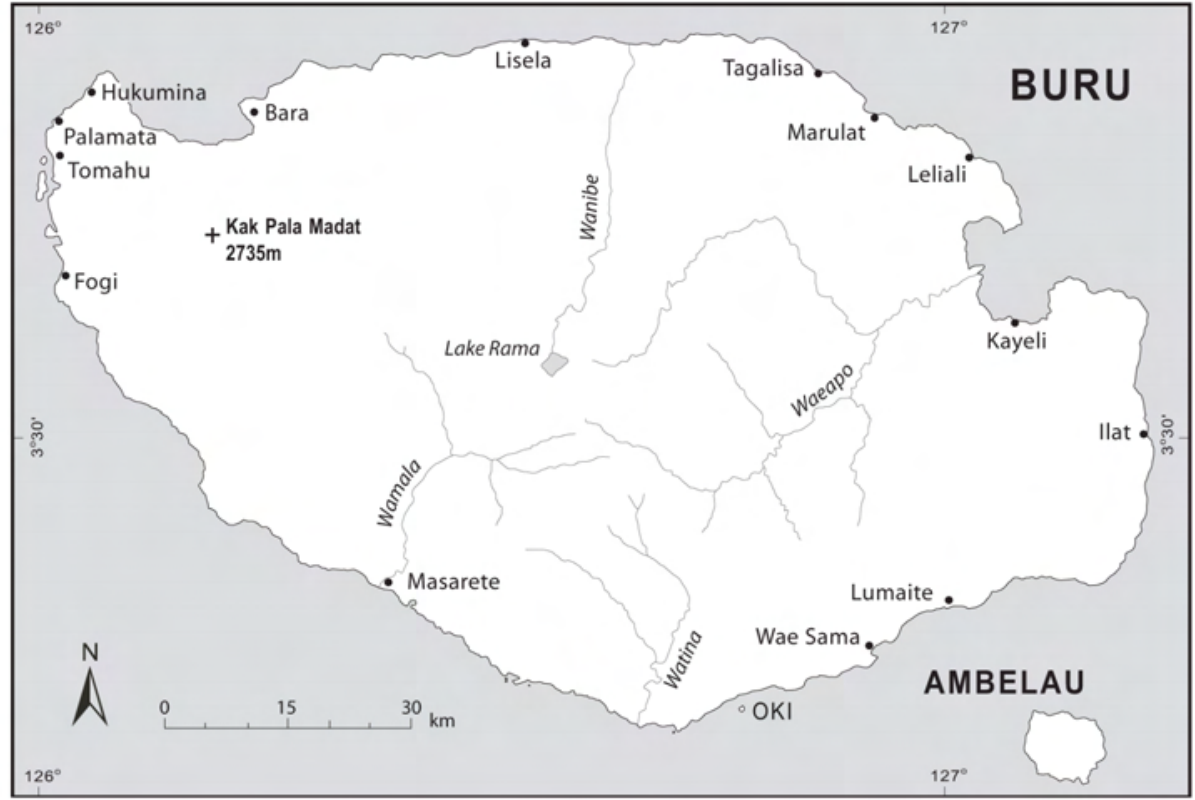

The same month the contract was signed, the Governor went to Kayeli Bay where a temporary fort was built, manned by 24 soldiers with four cannons. Thirteen separate villages were made around the fort, one for each of the villages from around the island which came to the fort: on the east side of the fort were the villages of Lumaite, Hukumina, Palamata, Tomahu and Masarete; Waisama lay to the south; and on the west side of the fort were Marulat, Leliali, Tagalisa, Ilat, Kayeli, Bara and Lisela (Rumphius 1983: 205). Each village had its own leader (Rumphius 1910, II: 118-21; Valentijn 1856, II: 197, 618). The coastal people of Buru were thus forced into a mixed community with the Dutch as their ever-present overlords, cut off from their former overseas allies and deprived of their local source of revenue from cloves.

Once the fort was established to keep an eye on the rebels, the next 150 years were ones of little change on Buru while the focus of VOC activity in Maluku was on the controlled clove-producing areas of Ambon and Lease. By the middle of the 19th century, approximately 2,000 people were living around the fort at Kayeli. Most of these people were Muslim villagers, still organised in their original villages from 200 years earlier. 
During this time, Kayeli was the only place of significance on Buru for the Dutch, who often equated Kayeli with all Buru. The Dutch consistently used the term orang Boeroe or 'Buru people' to refer to the Muslim villagers living around the fort, in contrast with the Alfuru, the natives living in the interior of the island.

A law passed as Staatsblad 19a of 1824 sought to reorganise local political systems with the goal of incorporating them into the colonial system. To do this on Buru, where there were only clans and no overarching political system, the Dutch had to appoint rajas and create regencies (Dutch regentschap). Because of the history of VOC involvement on Buru, they were able to find 14 raja in one convenient location-Kayeli.

With the passing of Staatsblad 19a in 1824, Buru was incorporated into the colonial administrative system by dividing the island into territories (regentschap) named after the former villages that had been removed to the fort at Kayeli in 1658. The current leader from each village in Kayeli was designated as regent for the regentschap of his ancestral village. With all the regents (who soon came to be referred to as raja) living there, Kayeli was the colonial capital of Buru just as it had been for the VOC.

\section{Map 4: Regentschap of Buru circa 1850}

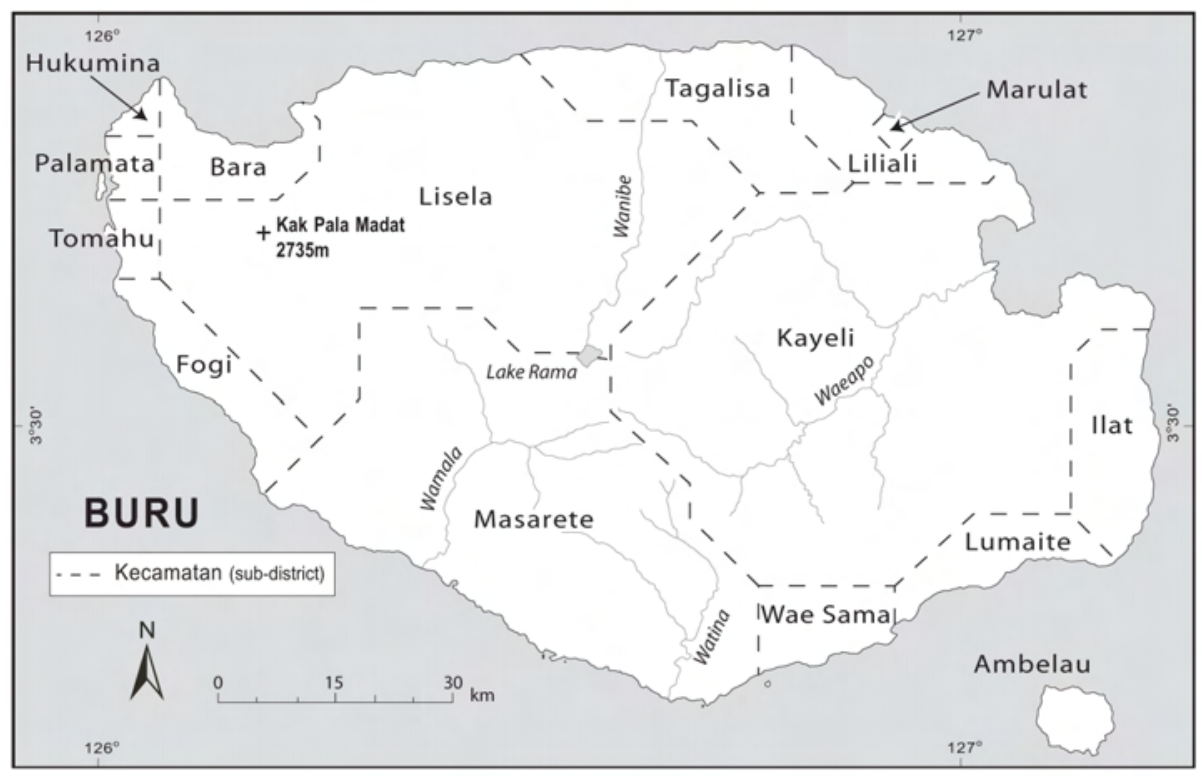

In this way, the Alfuru or indigenous people of Buru were officially mapped into the colonial system as subjects of the Muslim rajas at Kayeli. In the second part of the 19th century, however, some colonial officials began to express concern about this arrangement, claiming that the Buru rajas acted like despots 
in their treatment of the Alfuru, demanding large amounts of 'tribute' (enati) from each Buru clan in their regentschap. The tribute included baskets of rice, millet, coconuts, sago, sweet potatoes and tobacco, in addition to services requiring each clan to supply a given number of men on a periodic basis to work exclusively for the raja. Wilken $(1875: 6,7)$ noted that the tribute system was not an indigenous Alfuru idea, but had been introduced by the Muslim rajas who legitimated their authority over the Alfuru as coming from the supremacy of Ternate and Islam. For the Alfuru, the arrangement was unpleasant (the burden of tribute is still remembered today), but it was legitimated by their own notions that allowed rulers to be outsiders, illustrated by the following Alfuru explanation of why the Hentihu clan was raja of Lisela.

Once there was a Patti Buton, a leader of the Butonese immigrants to Buru whose family name was Hentihu, and a Patti Bessy, who was a local leader of the native Buru Nalbessy noro. The Patti Buton said to the Patti Bessy: 'Let's decide who will be the raja. We will each get a bucket of sand and whoever has the heaviest bucket will be the raja.' The Patti Bessy agreed and then the Patti Buton added: 'Because you are from the land, you walk landward to get sand, and because I am from the sea, I will walk seaward to get sand.' So that's what they did and of course the wet sand of the Patti Buton was heavier. This is why the raja of Lisela is an outsider, and why the Hentihu family from Buton has been raja for many generations. ${ }^{6}$

Some Kayeli rajas were well supplied with tribute from the Alfuru in their regentschap, but the Alfuru were not distributed equally in every regentschap. In fact, in some regentschap there appear to have been no or very few Alfuru. This might have been due partially to migration of the native people in the interior of the island as discussed above, but for whatever reason, the varying capacities of rajas to draw tribute from Alfuru created significant differences among them. As time passed, the rajas without Alfuru subjects faded away and their regentschap dropped off the maps of Buru as the boundaries were redefined to include only regentschap with Alfuru subjects (and wealthy rajas). In 1847, the regentschap of Maro, Hukumina, Palamata and Tomahu had no Alfuru(Willer 1858); by 1875, this included Bara and Ilat as well (Wilken 1875: 10).

Kayeli gradually began to decline. In the 1880s, the rajas of Leliali, Wae Sama and Fogi, along with most of their people, returned to their ancestral homes on coastal Buru after more than 200 years at the fort. About the turn of the century, the rajas of Leliali and Tagalisa did the same. By that time, the villages of Maroelat and Bara were extinct, and the ruling families of Hukumina, Tomahu and Lumaiti had died out. In their concern about the Muslim rajas' treatment of Alfurusubjects, in regentschap Masarete the Dutch appointed a new raja from an Alfuru clan who lived at Tifu on the coast of south Buru. By 1907 there were 
only 231 Muslims at Kayeli, compared with 1,400 50 years earlier (van der Miesen 1908: 836, 837). Today Kayeli is largely abandoned, and the old Dutch fort is half-sunk in a malarial swamp. Across the bay, the town of Namlea has replaced Kayeli as the major population centre, and is the new centre for the District of Buru Island (Kabupaten Pulau Buru).

In 1906, colonial laws were passed that changed the administrative system of governance in Java and Madura and then, in 1938, similar laws were passed for other areas. After independence, early Indonesian laws regarding administrative structure were based on the Dutch laws. While the regentschap system was no longer the official system of governance, rajas continued to be acknowledged, and several rajas were influential individuals serving in the Provincial Legislature in Ambon in the 1950s and 1960s.

\section{Map 5: Indonesian subdistricts (kecamatan): North-West Buru, North-East Buru and South Buru}

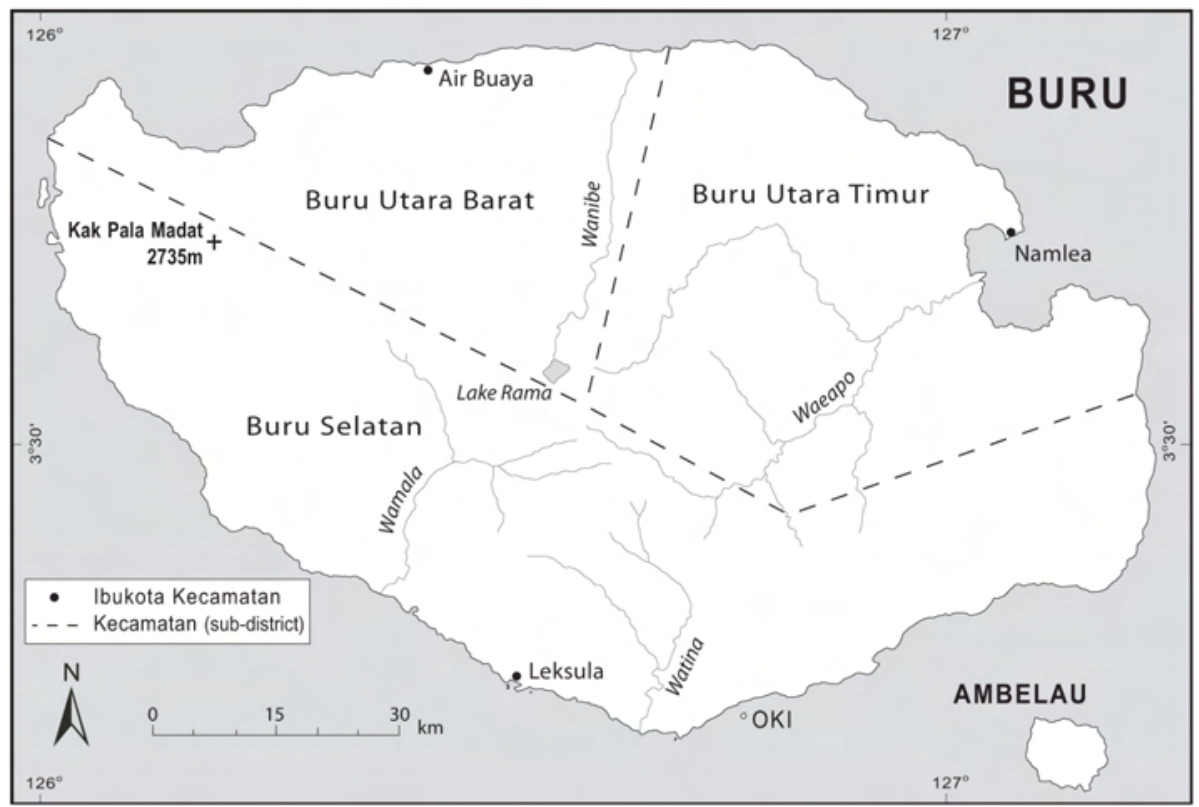

To Buru people, rajas were seen as 'guarding the doors to Buru', meaning their role was to interact with the outside, not the inside of society. To the Government, on the other hand, rajas (and regentschap) came to be seen as vestiges of Buru 'tradition' (adat). In the Government discourse of modernisation, however, tradition is antithetical to progress, so rajas and regentschap came to be seen as not relevant (and in some instances, hindrances) to the modern administrative system of camat (subdistrict head) and kecamatan. In the past few years, regional autonomy and traditional rights have been coming to the 
forefront of legislation and social debate in Indonesia. In Buru, as in Ambon and other places in Central Maluku, the beginning of a return to the authority of tradition has evoked a return to the authority of rajas, through a strong social forgetting that rajas were in fact colonial creations.

It still remains to be seen whether the recognition of Buru rajas will continue long term, partially because there are problems in regard to succession. Among the Muslim rajas, heredity is an established criterion for succession and the title passes from father to son or uncle to nephew. In regentschap such as Masarete, however, where the Dutch eventually appointed a native Christian rajas, heredity is not assumed, just as it is not assumed in the traditional Buru political system where noro members appoint noro leaders through consensus. In the past, the Dutch took an active role in appointing a new raja each time an old one died, but since the raja of Masarete died in 1986, the Indonesian Government has taken no such initiative, claiming it must come from the 'people'. The district head (bupati) was reported to have been willing to write a letter supporting whomever he was convinced had local support as raja. But from the perspective of Buru people in Masarete, rajas have always been entitled by outsiders, not by people inside Buru society. So with neither the government nor the local people seeing it as their responsibility to come up with a new raja, the system attenuates. A few individuals have had clear ambitions to be raja (including the former raja's eldest son), but no one can appoint himself, and so far no one has been successful in getting himself appointed by others.

Another reason for questioning the longer term survival of rajas on Buru is because egalitarianism between clans is very strong and there is no traditional space for political leadership higher than the clan. This egalitarianism is predicated largely on symmetrical marriage alliances. As is common in Austronesian societies, marriage creates an inherently asymmetric relationship with wife-givers superior to wife takers. On Buru this is expressed as the kori (the bride's parents and clan elders) holding the machete handle over the sanat (the groom's parents and clan elders). Sister exchange, however, referred to as the 'exchange of maidens' (emhuka eptukar), is arranged in a single set of marriage negotiations where the asymmetrical relationship is cancelled, as both parties are kori. The two bridegrooms in this case are said to be wali-tal-dawet (reciprocally both BW and $\mathrm{ZH}$ to each other) and their relationship reflects the ideals of friendship based on equality. Even without simultaneous sister exchange, the reciprocal exchange of women over time allows not just specific men but entire noro to see their overall relation as one of symmetry and equality. From this foundation of equality, Buru people stress that each clan should govern only its own clan, leaving no role for a raja inside society. 


\section{Map 6: Regentschap of Buru perceived as historical vestiges of Buru 'tradition' (adat) in 1991}

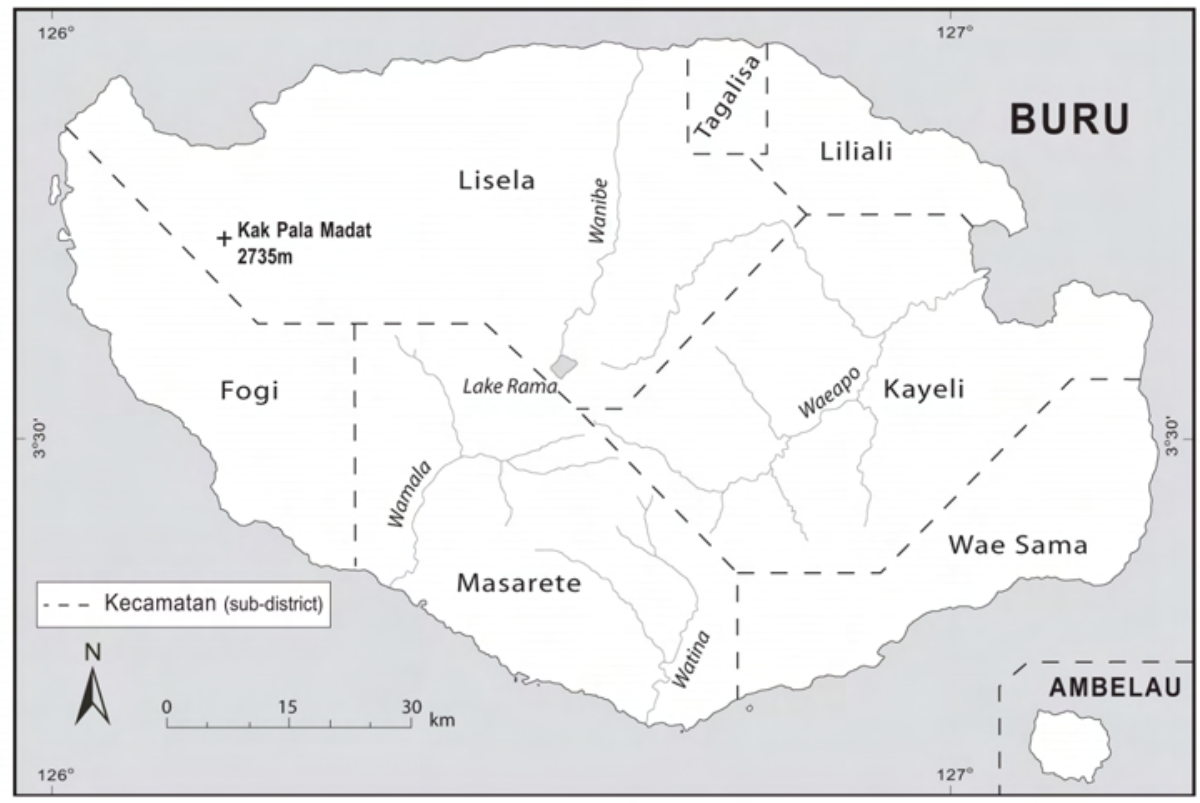

\section{The Indonesian Creation of Desa: Making the Outsider Village Head}

Another territorial construct that has been fraught with recent conflict on Buru is the Government's concept of desa, or administrative village. Concern for stronger mobilisation of forces for development at the desa level began to appear in the mid-1970s with the Government's five-year plan in 1978 stating:

It is important to ensure the success of development in all areas throughout Indonesia in order to achieve the desired national characteristics based on the Pancasila, that is, a just and prosperous society, both materially and spiritually for all people of Indonesia. So it is necessary to strengthen Desa government to be better able to mobilise the people in their participation in development and to carry out a broader and more effective village administration. (Yang penting adalah mensuksekan pembangunan di segala bidang di seluruh Indonesia, guna mencapai cita-cita Nasional berdasarkan Pancasila, yaitu masyarakat adil dan makmur, baik material maupun spiritual bagi seluruh rakyat Indonesia, maka perlu memperkuat pemerintah Desa agar makin mampu menggerakkan masyarakat dalam partisipasinya dalam pembangunan dan menyselenggarakan administrasi Desa yang makin meluas dan efektif.) (GBHN 1978) 
On December lof the next following year, the law known as UUPD (Udang-Udang Pemerintahan Desa-Laws of Village Governance) 1979 was passed by the Parliament. A major concern expressed in the preamble was that the old laws were no longer adequate because

in accord with the goals of national unity of the Republic of Indonesia, as far as possible the arrangement of Desa government needs to be made uniform as much as possible, by paying attention to the diversity that exists among Desa and the established local customs that still exist, in order to strengthen Desa government so that it is increasingly able to motivate the people to participate in development and to carry out Desa administration which is increasingly broad and effective. (bahwa sesuai dengan sifat Negara Kesatuan Repulik Indonesia maka kedudukan pemerintahan Desa sejauh mungkin diseragamkan, dengan mengindahkan keragaman keadaan Desa dan ketentuan adat istiadat yang masih berlaku untuk memperkuat pemerintahan Desa agar makin mampu menggerakan masyarakat dalam partisipasinya dalam pembangunan dan menyelenggarakan administrasi Desa yang makin meluas dan efektif.) (UUPD 1979)

The UUPD sought a uniform structure of village government throughout the nation whereby the lowest level of government in urban areas was to be the lurah and in rural areas the desa. The latter was defined as follows:

A Desa is an area in which is located a number of inhabitants as a social unit/unit of society including among it a legal unit of society which has the lowest governmental organization immediately below the Camat and has the right to organise its own households within the network of the national unity of the Republic of Indonesia. (Desa adalah suatu wilayah yang ditempati oleh sejumlah penduduk sebagai kesatuan masyarakat termasuk di dalamnya kesatuan masyarakat hukum yang mempunyai organisasi pemerintahan terendah langsung di bawah Camat dan berhak menyelenggarakan ruma tangganya sendiri dalam ikatan Negara Kesatuan Republik Indonesia.) (UUPD)

Among other things, the UUPD clearly laid out the requirements for each office-holder. For example, a village head had to be between 25 and 60 years old and a graduate of middle school (nine years of schooling) or have equivalent experience. It also detailed the oath the kepala desa and lurahs were to take on entering office, and how the election process was to be carried out. But many details and variables were still left to the discretion of various government officials.

To clarify some issues, in 1981, the Minister of Domestic Affairs (Mentri Dalam Negri) put out several letters of decision with more details about the 
structure of village government, the decisions that could be made by village governments (including how to type the letter of decisions), and how desa were to be formed, divided, joined and deleted. Of particular importance for Buru and Central Maluku were the requirements laid out for desa: a desaneeded to have a population of at least 2,500 people or 500 families. In creating desa, religious and socio-cultural factors needed to be considered, as well as the way of life of the inhabitants. And desa were to be created by decision of the Governor based on suggestions from district heads, after getting the agreement of the minister.

\section{Map 7: The boundaries of desa territories on Buru Island}

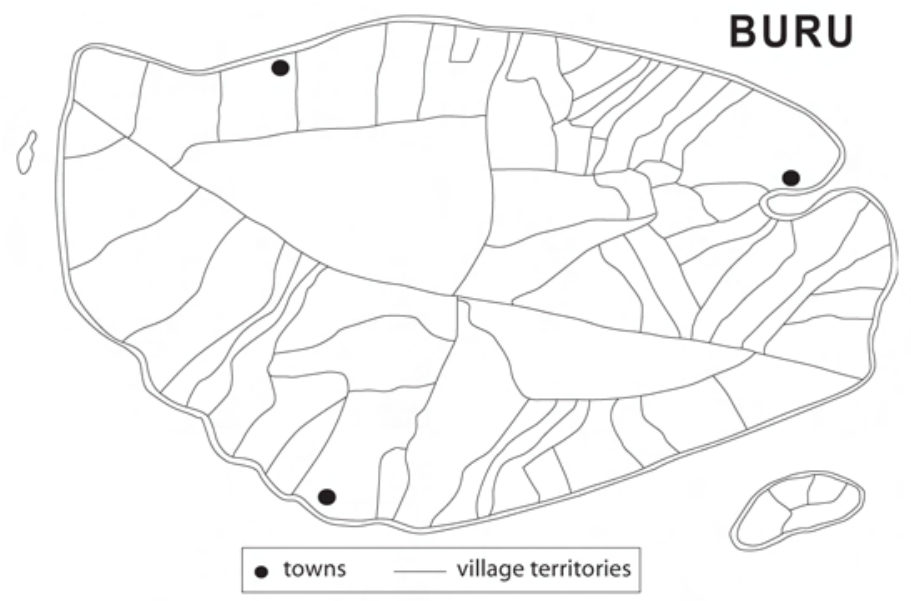

Given the size of the country, there is some common sense in the desire of the Indonesian State to have a uniform system of governance to facilitate development down to the village level (in 1983, there were 63,058 desa in Indonesia). However, the way desa were mapped onto Buru and elsewhere in Central Maluku created numerous problems. First, the large population size stipulated by the minister meant that in a place such as Buru, with a relatively low population density, a desa had to incorporate a huge area if it was to include 2,500 people or 500 families. ${ }^{7}$ Second, even though the minister stipulated that religious and ethnic factors should be considered, most desa boundaries were mapped onto Buru in total disregard of religion and ethnicity. Desa in Buru were drawn as parallel strips running inland from a small coastal area where an immigrant settlement was located. This meant that each desa encompassed coastal Muslim immigrants and interior Christian natives. Since it was far more convenient to reach settlements on the coast by boat (there are very few roads on Buru), candidates for village head were almost always selected by the camat from the coastal Muslim settlement rather than the interior. Buru people in the interior had learned to share their land with immigrants for many centuries, having only minimal interaction. But with the creation of these desa, more 
interaction was demanded. The Government policy of distributing cash to poor desa became particularly contentious, with people in the mountains repeatedly complaining that the money always stopped at the village head and none of it went upstream to them. ${ }^{8}$

\section{Conclusion: Mapping as Power}

Like many Austronesians, Buru people believe that land can and should be shared. They do this through the concept of fena, recognising the people who are the custodians of a fena, and those who have requested respectfully to live on a fena. Yet there is considerable conflict in Buru about boundaries and territories, not because land is a scarce resource, but because of the power relationships associated with different concepts of land. In the past two centuries, regentschap and desa have been mapped onto Buru. Both have proven to be disadvantageous to the native people of the island, by defining them as subjects liable for tribute to Muslim immigrant rajas, and by excluding them from government services, opportunities and aid, because they live in the remote interior rather than on the coast.

As I realised long ago, the map that is lacking is the map of Buru fena. Some on Buru also realise this lack as they are beginning to recognise the power of maps and land titles to legitimate land claims within the Indonesian national context. I was once requested to be a scribe for men from a Buru noro as they recited from memory the boundaries of their fena from a named river bed, to a named rock, to a mountain peak and so on. To them, fena is not just tradition handed down from their ancestors in the past, it is a valuable resource they hope to secure for their grandchildren in the future.

\section{References}

Anderson, Benedict. 1991. Imagined Communities: Reflections on the Origin and Spread of Nationalism. London: Verso.

Bellwood, Peter. 1985. Prehistory of the Indo-Malaysian Archipelago. New York: Academic Press.

Biro Pusat Statistik Buru. 1997. Buru Dalam Angka 1997 Namlea.

Blust, Robert. 1987. 'Lexical reconstruction and semantic reconstruction: the case of the Austronesian "house"'. Diachronica: International Journal for Historical Linguistics, 4 (1-2): pp. 79-106.

Chauvel, Richard. 1990. 'Nationalists, soldiers and separatists: the Ambonese islands from colonialism to revolt, 1880-1950.' Verhandelingen van het Koninklijk Instituut voor Taal-, Land-en Volkenkunde, 143. Leiden: KITLV Press. 
Dumond, D.E. 1969. 'Swidden Agriculture and the Rise of Maya Civilization.' In Andrew Vayda (ed.), Environment and Culture Behavior, Austin: University of Texas Press. pp 332-49.

Grimes, Charles E. 1991a. 'The Buru language of eastern Indonesia.' PhD dissertation, The Australian National University.

Grimes, Charles E. 1991b. 'Central Malayo-Polynesian: A critical evaluation.' Paper presented at the Sixth International Conference of Austronesian Linguistics' Honolulu.

Jansen, H.J. 1933. 'Gegevens over Boeroe (1928).' Adatrechbundels, 36. pp. 46389.

Kantor Statistik Kabupaten Maluku Tengah. 1987a. Kecamatan Buru Selatan dalam angka. Leksula.

Kantor Statistik Kabupaten Maluku Tengah. 1987b. Kecamatan Buru Utara Barat dalam angka. Air Buaya.

Kantor Statistik Kabupaten Maluku Tengah. 1987b. Kecamatan Buru Utara Timor dalam angka. Namlea.

McWilliam, Andrew R. 1999. 'From lord of the earth to village head; Adapting to the nation-state in West Timor.' BKI, 155-1. pp. 121-44.

Meggers, B.J. 1957. 'Environment and culture in the Amazon basin: An appraisal of the theory of environmental determinism.' In Studies in Human Ecology, Pan American Union, Social Science Monographs, No. 3, Washington.

Meilink-Roelofsz, M.A.P. 1962. Asian trade and European influence in the Indonesian archipelago between 1500 and about 1630. 's-Gravenhage: Martinus Nijhoff.

Rumphius, G.E. 1910. 'De Ambonsche historie, behelsende een kort verhaal der gedenkwaardigste geschiedenissen zo in vreede als oorlog voorgevallen sedert dat de Nederlandsche Oost Indische Comp. het besit in Amboina gehadt heeft.' 2 parts. Bijdragen tot de Taal-, Land-en Volkenkunde, 64.

Rumphius, G.E. 1983 [1674-78]. Ambonsche Landbeschrijving. Edited by Z.J. Manusama. Jakarta: Arsip Nasional.

Schut, J.A.F. 1921. 'Noro en fena op Boeroe.' Bijdragen tot de Taal-, Land-en Volkenkunde van Nederlandsch-Indië, 77. pp. 615-22.

Thongchai, Winichakul. 1988. 'Siam Mapped: A History of the Geo-Body of Siam.' Unpublished PhD thesis, University of Sydney, Sydney.

Valentijn, F. 1856-58 [1724-26]. Oud en Niew Oost-Indiën. 8 Vols. Amsterdam: Dordrecht. 
van der Miesen, J.W.H. 1908. 'Een tocht langs de noordoostkust van Boeroe.' Tijdschrift van het Koninklijk Nederlandsch Aardrijkskundig Genootschap te Amsterdam, 25/2. pp. 833-71.

van der Miesen, J.W.H. 1909a. 'Tochten op het eiland Boeroe.' Tijdschrift van het Koninklijk Nederlandsch Aardrijkskundig Genootschap te Amsterdam, 26/1. pp. 214-63.

van der Miesen, J.W.H. 1909b. 'Niewe tocht naar het eiland Boeroe.' Tijdschrift van het Koninklijk Nederlandsch Aardrijkskundig Genootschap te Amsterdam, 26/2. pp. 578-97.

Wilken, G.A. 1875. 'Bijdrage tot de kennis der Alfoeren van het eiland Boeroe.' Verhandelingen van het Bataviaasch Genootschap van Kunsten en Wetenschappen, 38. Batavia: Bruining and Wijt. pp. 1-61.

Willer, T.J. 1858. Het eiland Boeroe, zijne exploitatie en Halfoersche instellingen. Amsterdam: Frederik Muller.

www.websitercg.com/ambon/Buru.htm

\section{ENDNOTES}

1 This also predated the recent separation of North Maluku into a separate province.

2 Population is not distributed evenly on the island. About 70 per cent of the population lives on or near the coast, making the population density in the vast interior of the island much lower.

3 In the past, warfare also encouraged mobility. The mobility of Buru people in the vast interior of their island has been a significant survival strategy not only in the past, but also during the religious warfare between Muslims and Christians that spread to Buru from Ambon after January 1999.

4 This includes former political prisoners (referred to as tapol or tahanan politik in Indonesian) from the aftermath of 1965, who were interned in the Wae Apo River Valley. Years later, most were reclassified as transmigrants.

5 Official government statistics from 1997 list the religious affiliation of the population on Buru as 48 per cent Muslim, 41 per cent Christian and 11 per cent Other. These statistics are not disaggregated according to ethnicity, and do not explain the meaning of 'other' religion (Buru Dalam Angka 1997).

6 This story was told to C. Grimes on the north coast of Buru in 1989 and is almost identical to one that was told to Jansen in 1928 (Jansen 1933), explaining why the regent of Lisela was a 'Butonese usurper' (Boetonneeschen usurpator).

7 In some places in Indonesia, desa were formed with populations smaller than the official requirement. The relevance for Buru is that, although smaller desa would have been more appropriate socially, Buru social structure and residence patterns were ignored, and Buru people had little voice in the formation of these 'outside' political units.

8 In contrast with Buru where government positions such as village head (kepala desa) are filled largely by 'outsiders', see McWilliam (1999) in which he describes how traditional leaders in West Timor have been subsumed into the desa system as village heads. Given this scenario, a West Timorese village head/traditional leader 'emerges as a mediator between the competing demands of government and tradition'. On Buru, however, the competing demands of 'government' (pemerintah) and 'tradition' (adat) lack such a degree of mediation and the indigenous people continue to view 'government' largely as an outside system with outside agents attempting to exert control over their lives. 